\title{
IMPACTS OF SINKHOLES ON SALINITY LEVEL OF GROUNDWATER IN FINEGAYAN AREA, GUAM, USA
}

\author{
Yuming Wen ${ }^{1, *}$, John Jenson ${ }^{1}$ \\ ${ }^{1}$ Water and Environmental Research Institute, University of Guam, Mangilao, GU 96923, USA \\ *Email:ywen@triton.uog.edu
}

\begin{abstract}
Guam is a strategic location for the United States of America, which is located in the western Pacific. Guam's economy is mainly supported by tourism and military related activities.

Because of buildup activities and increasing population of tourists in the following few years, much pressure has been imposed on water resources and water quality in Guam. With about 5,000 marines relocated to Guam from Okinawa in the next few years, the Finegayan area will be a concerned area for buildup activities.

Therefore, the study area for the project is located in the Finegayan area, and the research concentrates on application of LiDAR data to figure out sinkholes in the Finegayan area, and application of GIS in evaluating salinity levels from drinking wells, and locating wells with problems with salinity in the study area. More concerns are focused on relationship between sinkholes and salinity, and whether sinkholes affect salinity levels in the study area.
\end{abstract}

\section{INTRODUCTION}

Guam, an unincorporated U.S. territory in the western Pacific, is the largest (about $541.3 \mathrm{~km}^{2}$ ) and southernmost island in the Mariana Islands chain. Ground water supplies about $90 \%$ of the drinking water for the island's about 170,000 residents and over 1.5 million visitors annually, and aims to welcome 2 million of visitors in 2020 [1][2]. However, there is a serious concern that the projected population increase will severely compromise the island's drinking water supplies and have an unprecedented impact on water quality and quantity. In Guam, water is pumped from over 121 wells, most of which are located in the northern Guam [3]. The high porosity and rapid recharge characteristics of the northern Guam lens aquifer make it especially susceptible to contamination from urban runoff, chemical spills, effluents from septic tanks and sewage overflows. Because of run-off and human induced activities, and unreliable drinking water delivery systems and management [4], the potential for contamination is high. The relocation of about 5000 marines, their dependents and foreign labors to support buildup activities for the next few years impose pressure on availability and quality of water resources. Among the concerns of water contaminants and water quantity, baseline study on determination of contaminants and water quantity in Guam's groundwater monitoring wells was identified as one of the highest priority research needs for Guam. Based on the above statement, groundwater quality and quantity is a main concern in Guam. Since around 5,000 marines will be relocated to Guam, particularly the Finegayan area in the next few years, it's very important to evaluate whether relocation of the marines and their dependents, and related activities will affect the quantity and quality of the water resources, especially groundwater resources. Based on the concerns mentioned above, it is crucial to conduct research on water quantity and quality, and other environmental and ecosystem concerns affected by buildup activities in the Finegayan area. Some recent research on impacts of human induced activities on water quality and historical evaluation of the factors contributing to changes of groundwater salinity in the Northern Guam Lens Aquifer are discussed by Wen [5] and Simard et. al [6] respectively. However, this is no profound research on relationship between 
sinkholes and salinity or impacts of sinkholes on salinity in Guam. This research mainly focuses on how to use LiDAR data to figure out sinkholes in the Finegayan area, and application of GIS in evaluating salinity levels from drinking/monitoring wells, and locating wells with problems with salinity in the study area. Emphasis is imposed on evaluation of relationship between sinkholes and salinity, and whether sinkholes affect salinity levels in the study area. The Government of Guam agencies, particularly Guam Waterworks Authority (GWA) and Guam Environmental Protection Agency (GEPA), and U.S. federal government agencies are interested in groundwater quality and quantity in Guam, including the Finegayan area. Findings from the project will help local and federal government agencies, and other interested parties in better understanding and management of the Finegayan Area, and therefore will facilitate buildup activities in the area.

\section{METHODOLOGY}

\subsection{Study Area and Data Sources}

Guam is a U.S. territory in the western Pacific. It is close to some major countries in the western Pacific region, including China, Australia, Japan, Korea, and the Philippines. It takes about 4 or 5 hours by air from Guam to some major cities such as Manila, Hong Kong, Shanghai, Seoul, and Tokyo in the region. The study area for this research is located in the northwestern part of Guam (Figure 1).

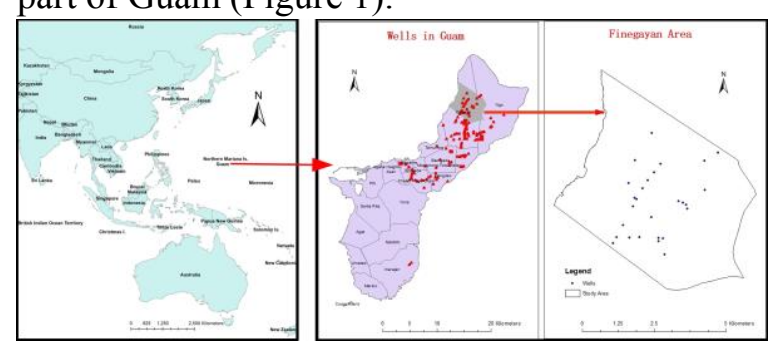

Figure 1. Location of Study Area

Available data for the research include boundary data for basins and Guam municipalities, bare earth data derived from LiDAR data of 2007, wells, chloride data collected quarterly from 2001 to 2009.

\subsection{Methods}

In order to evaluate the impacts of sinkholes on salinity of groundwater in the Finegayan area, salinity data and sinkholes need to be collected. GWA samples water from wells and tests the samples for contaminants including chlorides quarterly. Chloride data used for this research was collected between 2001 and 2009. Since the data of chlorides available from GWA is stored in the format of MS Excel spreadsheet, it needs to be geocoded and saved in a GIS format (In this case, it is saved in a shapefile) so that it can be further processed and analyzed in GIS. Spatial analysis is applied to locate wells with problems with high levels of salinity. As for sinkholes, LiDAR data of 2007 is employed. The bare earth data processed from the LiDAR point cloud data of 2007 is utilized to analyze the locations of sinkholes in the study area. GIS is the main tool applied to figure out wells with problems with salinity and sinkholes. Geospatial analysis and statistics are used to evaluate the relationship between salinity levels of groundwater from wells and locations of sinkholes.

\section{RESULTS}

\subsection{Salinity Problems in the Finegayan Area}

There are 27 wells considered in the Finegayan area, and data of chlorides for this research is available from GWA, collected from 2001 to 2009. Based on U.S. EPA's regulations, the suggested maximum contaminant level (MCL) for chloride, an indicator for salinity, is 250 $\mathrm{mg} / \mathrm{L}$. Based on spatial analysis of the chloride data, three wells are significant in salinity levels, three wells with a few occurrences with salinity levels over MCL and there are no salinity problems in all other wells. During the period of sampling, 23 samples for Well F-10, 21 samples for Well F-6 and 19 samples for Well F-13 out 
of 24 samples exceed the MCL of $250 \mathrm{mg} / \mathrm{L}$. Those three wells with non-significant problems with salinity are Wells F-19, F-4 and F-12.

\begin{tabular}{|c|c|c|}
\hline \multirow[t]{7}{*}{ Sal inithy. Problems in Finegayan Area } & Well ID & Frequency \\
\hline & F-10 & 23 \\
\hline & F-6 & 21 \\
\hline & F-13 & 19 \\
\hline & F-19 & 6 \\
\hline & F-4 & 4 \\
\hline & F-12 & 1 \\
\hline
\end{tabular}

Figure 2. Salinity Problems in Finegayan Area

\subsection{Sinkholes in the Finegayan Area}

The LiDAR data of 2007 includes two pieces of information, i.e. first return and last return data. The first return point cloud data is applied to achieve bare earth data, which can be employed to locate sinkholes and other information related to elevations. The spatial resolution of the digital elevation model (DEM) data for the bare earth derived from the LiDAR data is 1 meter by 1 meter. ArcGIS Spatial Analyst Tools such as hydrology and Map Algebra are utilized to obtain sinkholes in the study area (Figure 3). First of all, spatial analysis is applied to locate land depressions in the study area. The left map in Figure 3 indicates all land depressions based on the bare earth LiDAR data, the center map shows all land depressions with areas more than 10 square meters $\left(\mathrm{m}^{2}\right)$, and the left map manifests the preliminary result of delineated sinkholes with areas greater than $10 \mathrm{~m}^{2}$, and average depths at least about one foot.

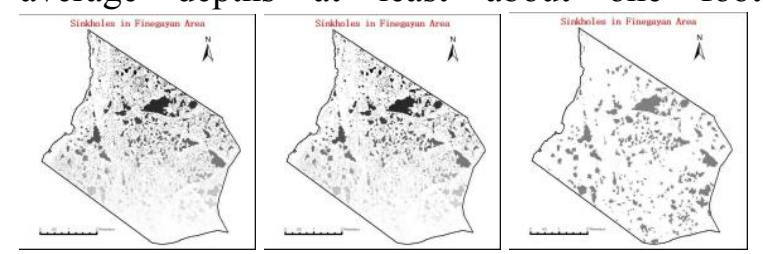

Figure 3. Sinkholes in Finegayan Area. Top: All land depressions; Center: Land depressions more than $10 \mathrm{~m}^{2}$; Bottom: Preliminary Sinkholes.

\subsection{Impacts of Sinkholes on Salinity}

The sinkholes may affect salinity levels in different ways. This research discusses whether areas and numbers of sinkholes located in buffer zones of specific distances to wells affect salinity levels in the study area. Table 1 demonstrates the relationship between some characteristics of sinkholes and wells. Buffer 50 means using buffer distance of 50 meters to create buffer zones for concerned wells. Same explanation exists for Buffer 100 and Buffer 150. It indicates that there are no sinkholes within 50 meters to Wells F-10, F-13 and F-19. There are no sinkholes within 100 meters to Well F-13. It seems that sinkholes have impacts on salinity levels for Wells F-6, F-4 and F-12, though they may not affect Wells F-4 and F-12 significantly. Sinkholes can be located within 150 meters to all problematic wells with salinity.

\begin{tabular}{|c|c|c|c|c|c|r|}
\cline { 2 - 7 } \multicolumn{1}{c|}{} & \multicolumn{2}{c|}{ Buffer 50 } & \multicolumn{2}{c|}{ Buffer 100 } & \multicolumn{2}{c|}{ Buffer 150 } \\
\hline Well_ID & Area $\left(\mathrm{m}^{2}\right)$ & \# of Sinkholes & Area $\left(\mathrm{m}^{2}\right)$ & \# of Sinkholes & Area $\left(\mathrm{m}^{2}\right)$ & \# of Sinkholes \\
\hline F-10 & 0 & 0 & 2280 & 1 & 8600 & 2 \\
\hline F-6 & 5299 & 2 & 23058 & 2 & 34455 & 3 \\
\hline F-13 & 0 & 0 & 0 & 0 & 134 & 1 \\
\hline F-19 & 0 & 0 & 5014 & 1 & 18677 & 2 \\
\hline F-4 & 3103 & 2 & 5314 & 4 & 16374 & 6 \\
\hline F-12 & 3 & 1 & 3089 & 2 & 8600 & 3 \\
\hline
\end{tabular}

Table 1. Relationship between Sinkholes and Wells with Salinity Problems

\subsection{Discussions}

Sinkholes have impacts on salinity levels to some degrees in the study area. More efforts will be invested to evaluate whether sizes, depths, distances to wells, fragmentation and distribution of sinkholes affect salinity levels. Other factors may also affect salinity levels. Those factors may include hydrological features such as slope and slope length, vegetation types, geological features, well pumping rates, human induced activities including ponding basins and other man-made structures, and climate factors such as El Niño and La Niña.

\section{ACKNOWLEDGEMENTS}

This project is partly funded by USGS 104b Program, and Guam Hydrological Survey. 


\section{REFERENCES}

[1] Guam Visitors Bureau (GVB), Tourism 2020, Tumon, Guam. (2014)

[2] GVB, 2018 Annual Summary. (2019)

[3] Guam Waterworks Authority, 2017 Annual Water Quality Report, Upper Tumon, Guam.

(2018)

[4] EPA Pacific Southwest/Region 9, EPA Progress Report 2006, San Francisco, California (2006)

[5] Y. Wen, Impacts of Human Activities on Groundwater Quality in Guam, Mariana Islands, International Journal of Environmental, Cultural, Economic and Social Sustainability, Vol. 7, Issue 5, pp 243-256 (2011)

[6] C. Simard, et al. Salinity in the Northern Guam Lens Aquifer, Technical Report 143, Water and Environmental Research Institute of the Western Pacific, University of Guam (2015) 